\title{
Elevated body fat is a risk factor for venous thromboembolism and thrombotic complications
}

\author{
Aránzazu García-Raso* and Pilar Llamas Sillero \\ *Correspondence: argarciar@fjd.es \\ CrossMark \\ $\leftarrow$ Click for updates
}

Division of Hemostasis and Thrombosis, Department of Hematology, University Hospital Fundación Jiménez Díaz, Avenida de los Catholic Kings, n², 28040, Madrid, Spain.

\begin{abstract}
Objective: The aim of the study is to analyze the relationship between body composition and BMI with venous thromboembolism (VTE) and major complications: recurrence and post-thrombotic syndrome.

Patients and methods: We performed a case-control study of a group of patients with VTE ( $\mathrm{n}=138)$ and a control group (n=127) with no history of thrombosis. BMI was calculated using the formula: BMI=weight $(\mathrm{kg}) / \mathrm{height}^{2}(\mathrm{~m})$. The body composition of each subject was obtained by bioelectrical impedance analysis using the TBF $300 \mathrm{a}$ analyzer.

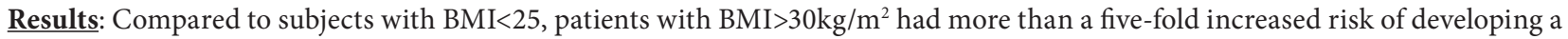
thrombotic event (OR: 5.47; 95\% CI: 2.56-12.22) and patients with BMI between $25-30 \mathrm{~kg} / \mathrm{m}^{2}$, had a threefold increased risk (OR: 2.95; 95\% CI: 1.58-5.68). Patients with high body fat\% had more than twice the risk of having a thrombotic event (OR: 2.72; 95\% CI: 1.54-4.91). Higher body fat\% was associated with an increased thrombotic risk in women (OR: 9.48; 95\% CI: 4.16-23.82) but not in men (OR: 0.52; 95\% CI: 0.20-1.31).
\end{abstract}

Conclusion: Our results suggest that patients with elevated percentage of body fat are in a higher risk of develop a venous thrombotic event.

Keywords: Venous thromboembolism, obesity, BMI, body composition, recurrence, post-thrombotic syndrome

\section{Background}

Venous thromboembolism (VTE) is a disabling condition with a high probability of recurrence and potentially fatal. This condition is characterized by the formation of a thrombus in the venous system, preceded or followed by an inflammatory response of the vessel wall. When part of the clot breaks off, it can migrate through the circulatory system to the pulmonary artery, causing a pulmonary embolism (PE). The VTE is characterized by an acute presentation, but can be considered a chronic disease due to the complications in its natural course and because of the possibility of recurrence. Despite advances in antithrombotic therapy, VTE has still a high incidence. A significant number of the cases could have been avoided with the establishment of adequate antithrombotic prophylaxis [1]. In developed countries, thrombosis, considering the venous and arterial, is the leading cause of mortality in adult, exceeding more than 3 times a neoplastic disease deaths [1-6]. The VITAE study estimated that in Europe there are more than 1.5 million cases annually, with 435000 cases of PE and 684000 of symptomatic deep venous thrombosis (DVT) [1].

The most common complications of VTE are post-thrombotic syndrome (PTS) and pulmonary hypertension. Post-thrombotic syndrome generates a high rate of sick leaves and produces a variable degree of morbidity in patients. The other major complication of VTE is death by pulmonary embolism, which occurs in approximately $1-2 \%$ of patients $[7,8]$. PE has an incidence of $6 \%$ in the DVT in upper limbs (DVT-UL) compared to $15-32 \%$ in the DVT in lower limbs (DVT-LL). Post-thrombotic syndrome has an incidence of $5 \%$ in the upper extremities compared to $56 \%$ in the lower extremities [9]. Another complication of venous thrombosis are the recurrent events, presented in $2-5 \%$ of DVT-UL and $10 \%$ of the DVT-LL.

Obesity is a multifactorial chronic disease associated with several complications and increased mortality. In addition, obesity is predisposing risk factors for different diseases including type 2 diabetes, certain lung diseases, sleep apnea, pulmonary hypoventilation syndrome, osteoarthritis, cancer or certain gynecological disorders [10-12].

Currently, BMI is collected routinely in many of the studies on risk factors for VTE, and there are some studies that show an increased thrombotic risk with in patients with elevated BMI [13-16]. Obesity may increase the risk of thrombosis in 
different ways: via leptin, by increasing the activity of the coagulation cascade and by decreasing fibrinolysis. Leptin is a peptide produced by adipose tissue and it acts as a hormone in the hypothalamus, reducing appetite. In cases of obesity, leptin levels are elevated, so it creates a certain resistance to its action. Leptin has been associated with ADP-dependent platelet aggregation [17] and its levels correlate with levels of antigenic tPA (tissue plasminogen activator) [18]. Higher levels of tPA signify elevated concentrations of PAI- 1 .

Other changes are the result of the insulin resistance that occurs in obese patients, and others are due to excess of fat per se. One of them is high fibrinogen levels (hyperfibrinogenemia). Dysfunctional adipocytes produce IL-6, a direct stimulator of fibrinogen synthesis in the liver, contributing to increased plasma fibrinogen levels $[19,20]$. In addition, hyperinsulinemia stimulates the production of PAI- 1 in the liver, and the adipose tissue can also become a producer. Elevated levels of PAI-1 are associated with less fibrinolysis and elevated plasma fibrinogen levels [21].

Also, a higher percentage of body fat, especially in the abdominal area, may limit venous return, resulting in increased intra-abdominal pressure and decreased blood velocity in the femoral vein in many obese patients [18].

\section{Body composition}

$\mathrm{BMI}$ is the most widely used indicator of obesity for population samples, although there are some limitations to BMI interpretation. Some diseases and pathological conditions are accompanied by changes in the composition of the different body compartments such as fat-free mass, fat mass and total body water [22].

An excess of body fat plays a central role in the development of some diseases such as metabolic syndrome because of its relationship with lipids and blood pressure. Traditionally, BMI is considered a good indicator of obesity, but BMI is only the relationship between body weight and height. Body weight is determined by both fat mass and muscular mass, so in people with high muscle development BMI is uncertain.

To study the implication of obesity in the development of thrombosis, it is important differentiate between central obesity and peripheral obesity. Central obesity is defined as the deposition of fat in the trunk and visceral adipose tissue, and peripheral obesity refers to the accumulation of fat in the gluteal-femoral area. In the development of VTE and thrombotic complications-mainly in the lower limbs-peripheral obesity seems to play a more important role, blocking or hindering venous return.

Electrical bioimpedance has certain advantages over other techniques for the study of body composition, such as ease of use, cost, and safety. By sending a small electrical current through the body, we can calculate the resistance opposed to its flow by the tissues (impedance), and thus calculate body composition [23]. This technique is based on the higher electrolyte content and greater conductivity of muscle mass than fat.

\section{Patients and methods}

We performed a case-control study involving a group of patients with VTE and a control group with no history of thrombosis. This work was conducted in strict adherence of the Declaration of Helsinki and data protection laws (Law 15/1999 on Protection of Personal Data) and the protection of patient rights (Law 15/2002). In addition informed consent was obtained from all participants. This study was reviewed and approved by the Clinical Research Ethics Committee of the University Hospital Fundación Jiménez Díaz UH-FJD, where the studies were conducted.

The study included 138 patients with VTE (DVT-LL or PE) referred to the Hematology Department either for thrombophilia study or for control of coagulant therapy between January, 2009 and January, 2012. Following current hospital protocol, diagnosis of VTE and VTE recurrence were performed by physical examination (color and skin lesions, edema and asymmetry, peripheral pulses, characteristics of edema, skin temperature, etc.), and were confirmed by objective tests. Definitive diagnosis of DVT was based on the results of Doppler ultrasound imaging. Cases of PE were diagnosed after a high-probability V/Q scan, and in cases in which was necessary a pulmonary angiography to confirm the diagnosis. The group of patients was subjected to a mean follow-up of $40( \pm 21)$ months in order to evaluate the occurrence of thrombotic complications. Diagnosis of PTS and the presence of residual thrombus were confirmed by objective testing (Doppler ultrasound) 3, 6 and 12 months after the acute event. Post-thrombotic syndrome was defined according to the CEAP clinical scale $[\mathbf{2 4 , 2 5 ]}$. To analyze the relationship of obesityrelated parameters with recurrence and PTS, we compared the group of patients with recurrent events or PTS, with the group of patients who did not develop recurrence or PTS, excluding the group of subjects with no history of thrombosis. Patients who were participating in a clinical trial at the time of this study, those in whom monitoring was not possible and patients who did not provide consent were excluded.

We included a control group of 127 unselected subjects from the same demographic area and same race as the group of patients with VTE. The control group was obtained by reviewing the medical histories of patients admitted to different departments of the UH-FJD. We included those patients who had no previous or current history of VTE or vascular disease (eg., myocardial infarction, ischemic heart disease, hypertensive heart disease, atrial fibrillation, ictus, peripheral vascular disease, claudication).

Demographic variables, age and sex, as well as classic cardiovascular risk factors (dyslipidemia, smoking, hypertension and diabetes mellitus) were collected from each patient. Cardiovascular risk factors were defined as follows: dyslipidemia (total cholesterol $>220 \mathrm{mg} / \mathrm{dl}, \mathrm{HDL}<35 \mathrm{mg} / \mathrm{dl}$, total cholesterol/ $\mathrm{HDL}$ cholesterol $>4.5$ or triglycerides $>200 \mathrm{mg} / \mathrm{dl}$, in at least 3 successive determinations; or use of hypolipidemic drugs), hypertension (diastolic blood pressure $>90 \mathrm{mmHg}$ and/or 
systolic blood pressure $>140 \mathrm{mmHg}$ detected 24 hours after admission on several measurements, or use of antihypertensive drugs preadmission), diabetes mellitus (DM) (fasting glucose $>38 \mathrm{mg} / \mathrm{dl}$ or prior use of oral hypoglycemic medications or insulin), smoking (regular consumption of more than 10 cigarettes per day at the time of enrollment or two years prior).

Height and weight were measured for each patient and control subject. From these measurements, BMI was calculated using the formula: $\mathrm{BMl}=$ weight $(\mathrm{kg}) / \mathrm{height}^{2}(\mathrm{~m})$. The measurements were performed on patients while they were wearing light clothing and barefoot. The weight measurement was obtained with a precision of $0.1 \mathrm{~kg}$ on a digital electronic scale. Our population was categorized according to their BMI as obese $\left(\mathrm{BMI}>30 \mathrm{~kg} / \mathrm{m}^{2}\right)$, overweight $\left(25<\mathrm{BMI} \leq 30 \mathrm{~kg} / \mathrm{m}^{2}\right)$, normal weight $\left(18<\mathrm{BMI} \leq 25 \mathrm{~kg} / \mathrm{m}^{2}\right)$ and underweight $(\mathrm{BMl}<18$ $\mathrm{kg} / \mathrm{m}^{2}$ ) according to the cut-off points proposed by the WHO.

For the study of BMI two types of analysis was performed, firstly the mean value of BMI was compared between the patient and the control group. Furthermore, the incidence of VTE, recurrence and PTS was analyzed in two groups according to $\mathrm{BMI}$, with reference to the group of subjects with $\mathrm{BMl}<25$ $\mathrm{kg} / \mathrm{m}^{2}$. These two groups were: 1 ) overweight: BMl: $25-30 \mathrm{~kg} /$ $\mathrm{m}^{2}$ and 2) obesity: $\mathrm{BMl}>30 \mathrm{~kg} / \mathrm{m}^{2}$.

\section{Body composition}

The body composition of each patient and control subject was obtained by bioelectrical impedance analysis using the TBF 300a analyzer (TANITA Corp., Arlington Heights, Japan). This protocol has been validated in several studies for different groups, including adults over 60 years [26] and postmenopausal women [27], among others. The measurements were performed with patients standing on the plates of the analyzer while wearing no shoes or socks. The analyzer measures body composition by using a continuous energy source that generates a stream of high frequency and low intensity $(50 \mathrm{kHz}, 500 \mu \mathrm{A})$ and with 4 pairs of bipolar electrodes. To calculate body composition, it was necessary to insert in the analyzer the variables: age, sex, height and physical activity.

Height measurements were collected prior to the calculation of BMI. The frequency of patients' physical activity was classified as standard or athletic based on the number of hours of activity they reported per week (standard, $<10$ hours of exercise a week, and athletic, $>10$ hours). All measurements were performed in duplicate with a one-minute gap between them.

For the study of body composition two types of analysis was performed, firstly the average value of body fat (BF) $\%$ and total $\mathrm{BF}(\mathrm{kg})$, in this case the mean values were compared between the patient group and the control group. Furthermore, the BF\% was analyzed considering the ideal values supplied by the analyzer, so we compared the cases with high $\mathrm{BF} \%$ versus those who had a normal BF\% or low BF\%. Finally, the amount of total BF $(\mathrm{kg})$ was analyzed by comparing patients in the highest quartile (Q3 and Q4) to patients in the lowest quartile (Q1 and Q2).

\section{Statistical analysis}

We conducted a descriptive study of the discrete variables, calculating the frequency and percentage of occurrence of each parameter. Two analyses were conducted: the variables were analyzed quantitatively, and then were categorized to study the subset of patients with normal parameters compared to those with high levels of weight, $\mathrm{BMI}$ and $\mathrm{BF} \%$. Descriptive statistics were calculated (mean, median, standard deviation and lower and upper quartiles) for quantitative variables. In the univariate logistic regression model, the presence or absence of thrombosis was taken as a dependent variable. All comparisons were performed with a significance level of 0.05 . The magnitude of association was calculated by the $O R$, estimated by logistic regression with confidence intervals at $95 \%(95 \% \mathrm{Cl})$. Comparisons of quantitative variables were performed using Student's t test or Mann -Whitney U test, depending on whether the variable was normally distributed or not. To study the association of categorical variables with VTE, contingency tables were obtained, and chi-square or Fisher's were used. We conducted a multivariate logistic regression analysis adjusting for age, sex and cardiovascular risk factors (hypertension, DM, dyslipidemia and smoke). To compare the differences between the groups, we performed a test of homogeneity, the OR was considered significant at $p<0.05$. Statistical analysis of the data was performed with Stata v 10 (StatCorp LP, USA).

\section{Results}

The mean age of the patients was $54.30( \pm 17.44)$ years, while in the controls it was $59.02( \pm 18.32)$ years $(p=0.0201)$. The patient group was composed of $42.3 \%(n=83)$ of men while in the control group men represented $39.4 \%(n=50)$. The baseline characteristics of patients and controls are shown in Table 1.

\section{Body mass index}

All subjects included in the study were classified by BMI: normal weight $\left(B M l<25 \mathrm{~kg} / \mathrm{m}^{2}\right)$, overweight $\left(25<\mathrm{BMl} \leq 30 \mathrm{~kg} / \mathrm{m}^{2}\right)$ and obesity $\left(\mathrm{BMI}>30 \mathrm{~kg} / \mathrm{m}^{2}\right)$. None of the patients or controls included in the study had BMI values $<18 \mathrm{~kg} / \mathrm{m}^{2}$. High BMI was found in $39.2 \%$ of patients with VTE. The mean BMI was significantly higher in the patient group $\left(28.26 \pm 6 \mathrm{~kg} / \mathrm{m}^{2}\right.$ vs $26.31 \pm 5.29 \mathrm{~kg} / \mathrm{m}^{2}$, OR: $1.07,95 \% \mathrm{Cl}: 0.007-1.09, \mathrm{p}=0.0021$ ).

When we estimated the association between $\mathrm{BMI}$ and VTE, the analysis showed that patients with $\mathrm{BMI}>30 \mathrm{~kg} / \mathrm{m}^{2}$ had a 5 -fold greater risk of developing a thrombotic event (OR: 5.47; $95 \% \mathrm{Cl}: 2.56-12.22)$, whereas in patients with BMI between 25$30 \mathrm{~kg} / \mathrm{m}^{2}$ (OR: $\left.2.95 ; 95 \% \mathrm{Cl}: 1.58-5.68\right)$, the risk was increased nearly threefold. The association with BMI remained after performing the analysis adjusting for age and sex (Table 2). The analysis was performed by sex, revealing differences between men and women (Table 3 ).

\section{Body composition}

BF\% was determined for 138 patients and 127 controls. After 
Table 1. Baseline characteristics of patients and controls.

\begin{tabular}{lllll}
\hline & Controls $(\mathbf{n}=\mathbf{1 2 7})$ & Patients $(\mathbf{n}=\mathbf{1 3 8})$ & $\mathbf{p}$ & OR $^{\ddagger}(\mathbf{9 5} \% \mathbf{C I})$ \\
\hline Age & $59.02(18.32)$ & $52.62(15.06)$ & 0.002 & $0.98(0.96-0.99)$ \\
Sex (women/men)n (\%) & $77 / 50(60.6 / 39.4)$ & $113 / 83(57.7 / 42.3)$ & 0.166 & $1.41(0.87-2.31)$ \\
BMI (SD) & $26.3(5.3)$ & $27.8(6.2)$ & 0.004 & $1.07(1.02-13)$ \\
Dyslipidemia n (\%) & $24(18.9)$ & $84(43.8)$ & $<0.0001$ & $3.87(2.72-5.56)$ \\
Hypertension n (\%) & $30(23.69)$ & $29(21)$ & 0.610 & $0.86(0.48-1.54)$ \\
Diabetes Mellitus n (\%) & $13(10.2)$ & $6(4.3)$ & 0.071 & $0.39(0.14-1.04)$ \\
Tobacco n (\%) & $17(13.4)$ & $40(29)$ & 0.025 & $2.64(1.43-5.06)$ \\
Obesity ${ }^{*}$ n (\%) & $19(15)$ & $38(27.5)$ & $<0.0001$ & $5.47(2.56-12.22)$ \\
\hline
\end{tabular}

${ }^{\star}$ Consider obesity as a BMI $>30 \mathrm{Kg} / \mathrm{m}^{2}$. $\ddagger$ OR adjusted by sex and age.

Table 2. Association between BMI and VTE.

\begin{tabular}{l|llll}
\hline \multirow{2}{*}{ BMI (kg/m²) } & \multicolumn{2}{|c|}{ Crude OR } & \multicolumn{2}{c}{ Adjusted OR } \\
\cline { 2 - 5 } & OR (95\% CI) & $\mathbf{p}$ & OR (95\% CI) & p \\
\hline $25-30$ & $2.37(1.36-4.21)$ & 0.0004 & $2.95(1.58-5.68)$ & $<0.0001$ \\
$>30$ & $3.56(1.79-7.29)$ & 0.0004 & $5.47(2.56-12.22)$ & $<0.0001$ \\
\hline
\end{tabular}

BMI: body mass index.

*Adjusted by sex, age and cardiovascular risk factors

(dislipydemia, tobacco, DM and hypertension).

Table 3. Association between BMI and VTE by sex.

\begin{tabular}{|c|c|c|c|c|c|c|}
\hline \multirow[t]{2}{*}{ WOMEN } & \multicolumn{2}{|c|}{ Mean \pm SD } & \multirow{2}{*}{\multicolumn{2}{|c|}{$\mathrm{OR}^{*}(95 \% \mathrm{CI}) \mathrm{p}$}} & \multirow[t]{2}{*}{$\mathrm{OR}^{\star}(95 \% \mathrm{CI})$} & \multirow[t]{2}{*}{$\mathbf{p}$} \\
\hline & VTE $(n=138)$ & Controls $(n=127)$ & & & & \\
\hline \multirow[t]{2}{*}{ BMI $\left(\mathrm{kg} / \mathrm{m}^{2}\right)$} & $27.6 \pm 5.5$ & $25.6 \pm 5.2$ & $1.09(1.02-1.18) 0.007$ & $25-30$ & $3.15(1.42-7.26)$ & 0.0005 \\
\hline & & & & $>30$ & $5.54(2.16-15.29$ & 0.0005 \\
\hline \multirow[t]{2}{*}{ MEN } & \multicolumn{2}{|c|}{ Mean \pm SD } & \multirow[t]{2}{*}{ OR $(95 \% \mathrm{CI}) \mathrm{p}$} & & \multirow[t]{2}{*}{ OR $(95 \% \mathrm{CI})$} & \multirow[t]{2}{*}{ p } \\
\hline & VTE $(n=138)$ & Controls $(n=127)$ & & & & \\
\hline \multirow[t]{2}{*}{ BMI $\left(\mathrm{kg} / \mathrm{m}^{2}\right)$} & $28.0 \pm 6.9$ & $27.4 \pm 5.3$ & $1.06(0.98-1.14) 0.1475$ & $25-30$ & $2.51(0.87-7.77)$ & 0.0616 \\
\hline & & & & $>30$ & $4.69(1.28-21.46)$ & 0.0616 \\
\hline
\end{tabular}

BMI: body mass index.

${ }^{\star}$ Adjusted by sex, age and cardiovascular risk factors (dislipydemia, tobacco, DM and hypertension).

the analysis, the subjects were classified according to the ideal $\mathrm{BF} \%$ parameters provided by the analyzer as low, normal (divided into 2 categories: low and high) and high. High BF\% was found in $60 \%$ of patients with VTE, whereas in the control group this percentage was 14 . We analyzed the association of thrombosis with body composition of patients, studying two variables: body fat (\% BF) and fat mass ( $\mathrm{kg}$ ). Slight significant difference was found in the mean value of $\mathrm{BF} \%$ between patients and controls $(29.83 \pm 9.71$ vs $29.1 \pm 9.00$ OR: 1.05 ; $95 \% \mathrm{Cl}: 1.02-1.09, \mathrm{p}=0.004)$ and in the average value of the amount of $\mathrm{BF}(\mathrm{kg})(23.5 \pm 9.98$ vs $21.8 \pm 8.87, \mathrm{OR}: 1.03 ; 95 \% \mathrm{Cl}$ : 1.00-1.06, $\mathrm{p}=0.025$ ).

We estimated the association \%BF and the BF $(\mathrm{kg})$ with VTE. Patients with $\mathrm{BF} \%$ above the ideal values were at twice the risk of having a thrombotic event (OR: $2.72 ; 95 \% \mathrm{Cl}: 1.54-4.91$ ).
For BF ( $\mathrm{kg})$, a significant association was found in two analyzed quartiles (Table 4). When the patients were analyzed by sex, the results revealed some differences between men and women. Table 5 shows the results obtained in the analysis adjusted for age, sex and thrombotic risk factors. Higher $\mathrm{BF} \%$ was associated with an increased thrombotic risk only in women (OR: 9.48; 95\% Cl: 4.16-23.82).

\section{Thrombotic complications}

The relationship between obesity and the occurrence of recurrent thrombotic events was analyzed. Of the total group, 60 patients developed recurrent events during the follow-up period. We estimated the association of recurrence with $\mathrm{BMI}$, $\mathrm{BF} \%$ and the amount of BF (kg). We found no statistically significant association of either of these variables with 
recurrence (Table 6). Additionally, we studied $\mathrm{BMI}, \mathrm{BF} \%$ and the amount of BF $(\mathrm{kg})$. These three values were higher in the group of patients with PTS. However, no statistically significant association with PTS was found (Table 7).

\section{Discussion}

We conducted a case-control study in which we analyzed the relationship between obesity and venous thromboembolic disease. The study has some limitations, since BMI and body composition can vary over time. In our study, these parameters were collected only once-at the time of patient inclusion - so possible variations occuring in the association with VTE have not been accounted for. On the other hand, excess body weight evaluated as BMI is not a good estimate of fat distribution. Indicators of central obesity, including waist circumference or waist/hip ratio, may provide complementary information. Some of the odds ratios presented in this manuscript indicate a certain degree of association between $\mathrm{BMI}$ and $\mathrm{BF} \%$, and VTE, but suffer from statistical uncertainty (very wide $95 \%$ confidence intervals). This is an important limitation of the study.

$\mathrm{BMI}$ analysis showed that patients with BMI between 25-30 $\mathrm{kg} / \mathrm{m}^{2}$ have twice the thrombotic risk than subjects with $\mathrm{BMl}<25$ $\mathrm{kg} / \mathrm{m}^{2}$, while patients with $\mathrm{BMl}>30 \mathrm{~kg} / \mathrm{m}^{2}$ have five times the risk of developing a thrombotic event. When analyzing the variables according to sex, we found that the thrombotic risk associated with high BMI was greater in women than in men.

Table 4. Association of body fat and VTE.

\begin{tabular}{|c|c|c|c|c|c|c|}
\hline & \multicolumn{2}{|c|}{$\operatorname{Mean} \pm$ SD } & \multirow{2}{*}{\multicolumn{2}{|c|}{$\mathrm{OR}^{\star}(95 \% \mathrm{CI}) ; \mathrm{p}$}} & \multirow[t]{2}{*}{$\mathrm{OR}^{\star}(95 \% \mathrm{CI})$} & \multirow[t]{2}{*}{$\mathbf{p}$} \\
\hline & $\operatorname{VTE}(n=138)$ & Controls $(n=127)$ & & & & \\
\hline $\mathrm{BF} \%$ & $29.83 \pm 9.71$ & $29.1 \pm 9.00$ & $1.05(1.02-1.09) ; 0.004$ & High & $2.72(1.54-4.91)$ & 0.0005 \\
\hline \multirow{2}{*}{$\mathrm{BF}(\mathrm{kg})$} & \multirow{2}{*}{$23.5 \pm 9.98$} & \multirow{2}{*}{$21.8 \pm 8.87$} & \multirow{2}{*}{$1.03(1.00-1.06) ; 0.025$} & Q3 & $2.04(1.09-3.89)$ & \multirow{2}{*}{0.011} \\
\hline & & & & Q4 & $2.57(1.31-5.19)$ & \\
\hline
\end{tabular}

BF\%: percentage of body fat, BF (kg): body fat (kg).Q3: third quartile (21.1-27.9) kg, Q4: forth quartile (>27.9) kg. ${ }^{\star}$ Adjusted by sex, age and cardiovascular risk factors (dislipydemia, tobacco, DM and hypertension).

Table 5. Relationship of body composition with VTE in men and women.

\begin{tabular}{|c|c|c|c|c|c|c|}
\hline \multirow{2}{*}{ WOMEN } & \multicolumn{2}{|c|}{ Mean \pm SD } & \multirow{2}{*}{\multicolumn{2}{|c|}{$\mathrm{OR}^{\star}(95 \% \mathrm{CI}) ; \mathrm{p}$}} & \multirow{2}{*}{$\mathrm{OR}^{\star}(95 \% \mathrm{CI})$} & \multirow{2}{*}{$\mathbf{p}$} \\
\hline & $\operatorname{VTE}(n=138)$ & Controls $(n=127)$ & & & & \\
\hline $\mathrm{BF} \%$ & $35.4 \pm 8.2$ & $32.5 \pm 8.4$ & 1.07 (1.02-1.12); 0.004 & High & $9.48(4.16-23.82)$ & $<0.0001$ \\
\hline \multirow{2}{*}{$\mathrm{BF}(\mathrm{kg})$} & \multirow{2}{*}{$26.0 \pm 10.0$} & \multirow{2}{*}{$23.2 \pm 9.0$} & \multirow{2}{*}{$1.04(1.01-1.08) ; 0.0236$} & Q3 & $2.47(1.06-5.92)$ & \multirow{2}{*}{0.017} \\
\hline & & & & Q4 & $3.14(1.37-7.50)$ & \\
\hline \multirow{2}{*}{ MEN } & \multicolumn{2}{|c|}{ Mean \pm SD } & \multirow{2}{*}{\multicolumn{2}{|c|}{ OR $(95 \% \mathrm{CI}) ; \mathrm{p}$}} & \multirow{2}{*}{ OR $(95 \% \mathrm{CI})$} & \multirow{2}{*}{$\mathbf{p}$} \\
\hline & $\operatorname{VTE}(n=138)$ & Controls $(\mathrm{n}=127)$ & & & & \\
\hline $\mathrm{BF} \%$ & $23.7 \pm 7.2$ & $24.0 \pm 7.3$ & 1.02 (0.96-1.08); 0.519 & High & $0.52(0.20-1.31)$ & 0.1658 \\
\hline \multirow{2}{*}{$\mathrm{BF}(\mathrm{kg})$} & \multirow{2}{*}{$20.7 \pm 9.3$} & \multirow{2}{*}{$19.8 \pm 8.4$} & \multirow{2}{*}{$1.01(0.96-1.06) ; 0.699$} & Q3 & $1.45(0.52-4.14)$ & \multirow{2}{*}{0.616} \\
\hline & & & & Q4 & $1.70(0.47-6.68)$ & \\
\hline
\end{tabular}

BF\%: percentage of body fat, BF $(\mathrm{kg})$ : body fat $(\mathrm{kg})$.Q3: third quartile (21.1-27.9) $\mathrm{kg}$, Q4: forth quartile (>27.9) kg. *Adjusted by sex, age and cardiovascular risk factors (dislipydemia, tobacco, DM and hypertension).

Table 6. Association of BMI, BF\% and BF (kg) with thrombotic recurrence.

\begin{tabular}{|c|c|c|c|c|c|c|}
\hline & \multicolumn{2}{|c|}{ Mean \pm SD } & \multirow{2}{*}{\multicolumn{2}{|c|}{$\mathrm{OR}^{\star}(95 \% \mathrm{CI}) ; \mathrm{p}$}} & \multirow{2}{*}{$\mathrm{OR}^{\star}(95 \% \mathrm{CI})$} & \multirow{2}{*}{$\mathbf{p}$} \\
\hline & Recurrence $(n=60)$ & No recurrence $(n=78)$ & & & & \\
\hline \multirow{2}{*}{ BMI $\left(\mathrm{kg} / \mathrm{m}^{2}\right)$} & \multirow{2}{*}{$27.8 \pm 6.9$} & \multirow{2}{*}{$27.7 \pm 5.5$} & \multirow{2}{*}{1.00 (0.94-1.06); 0.995} & $25-30$ & $0.87(0.35-2.14)$ & \multirow{2}{*}{0.946} \\
\hline & & & & $>30$ & $0.95(0.34-2.63)$ & \\
\hline $\mathrm{BF} \%$ & $28.4 \pm 10.7$ & $31.0 \pm 8.7$ & 0.96 (0.91-1.00); 0.076 & High & $0.68(0.25-1.55)$ & 0.313 \\
\hline \multirow[t]{2}{*}{$\mathrm{BF}(\mathrm{kg})$} & \multirow[t]{2}{*}{$23.0 \pm 10.6$} & \multirow[t]{2}{*}{$23.9 \pm 9.5$} & \multirow[t]{2}{*}{$0.99(0.96-1.03) ; 0.719$} & Q3 & $0.84(0.35-1.99)$ & \multirow[t]{2}{*}{0.919} \\
\hline & & & & Q4 & $0.97(0.39-2.37)$ & \\
\hline
\end{tabular}

OR adjusted for age and sex. BF\%: percentage of body fat, $\mathrm{BF}(\mathrm{kg})$ : body fat $(\mathrm{kg})$. Q3: third quartile (21.1-27.9) $\mathrm{kg}$, Q4: forth quartile (>27.9) kg. *Adjusted by sex, age and cardiovascular risk factors (dislipydemia, tobacco, $\mathrm{DM}$ and hypertension). 
Garcia-Raso et al. Epidemiology Reports 2014,

http://www.hoajonline.com/journals/pdf/2054-9911-2-3.pdf

doi: $10.7243 / 2054-9911-2-3$

Table 7. Association of BMI, BF\% and BF (kg) with PTS.

\begin{tabular}{|c|c|c|c|c|c|c|}
\hline & \multicolumn{2}{|c|}{ Mean \pm SD } & \multirow{2}{*}{\multicolumn{2}{|c|}{$\mathrm{OR}^{\star}(95 \% \mathrm{CI}) ; \mathrm{p}$}} & \multirow{2}{*}{$\mathrm{OR}^{*}(95 \% \mathrm{CI})$} & \multirow{2}{*}{$\mathbf{p}$} \\
\hline & PTS $(n=51)$ & No PTS $(n=87)$ & & & & \\
\hline \multirow{2}{*}{ BMI } & \multirow{2}{*}{$28.2 \pm 4.9$} & \multirow{2}{*}{$27.5 \pm 6.8$} & \multirow{2}{*}{1.03 (0.97-1.09); 0.280} & $25-30$ & $1.01(0.40-2.56)$ & \multirow{2}{*}{0.637} \\
\hline & & & & $>30$ & $1.48(0.54-4.15)$ & \\
\hline $\mathrm{BF} \%$ & $30.1 \pm 8.6$ & $29.7 \pm 10.3$ & 0.99 (0.94-1.03); 0.549 & High & $0.99(0.37-2.44)$ & 0.945 \\
\hline \multirow{2}{*}{$\mathrm{BF}(\mathrm{kg})$} & \multirow{2}{*}{$23.9 \pm 8.7$} & \multirow{2}{*}{$23.3 \pm 10.7$} & \multirow{2}{*}{1.00 (0.96-1.04); 0.949} & Q3 & $1.75(0.72-4.32)$ & \multirow{2}{*}{0.463} \\
\hline & & & & Q4 & $1.34(0.53-3.39)$ & \\
\hline
\end{tabular}

$\mathrm{BF} \%$ : percentage of body fat, $\mathrm{BF}(\mathrm{kg})$ : body fat $(\mathrm{kg})$.Q3: third quartile $(21,1-27,9) \mathrm{kg}$,

Q4: forth quartile $(>27,9) \mathrm{kg}$. ${ }^{*}$ Adjusted by sex, age and cardiovascular risk factors

(dislipydemia, tobacco, DM and hypertension).

By analyzing the relationship of body fat (\%) with VTE, a significant association was found in women, but not for men. VTE patients with a high percentage of $\% B F$ had a two-fold higher risk than those in whom $\mathrm{BF} \%$ was within the ideal values (OR: 2.72). When the analysis was performed by sex, the risk associated with elevated $\mathrm{BF} \%$ in women was OR: 9.48 .

The pathophysiological mechanisms by which obesity increases the risk for thrombosis are different: inflammation, oxidative stress, dyslipidemia and insulin resistance. It also seems to have direct effects on the coagulation cascade and the fibrinolytic system. The physical characteristics of obese patients may contribute to the risk of VTE. More body fat especially abdominal fat- may limit venous return. Obese patients have elevated intra-abdominal pressure and decreased blood flow in the femoral vein [28]. The study of the parameters used to characterize venous flow in the lower extremities of obese and non-obese healthy subjects has shown significant differences between the two groups, being lower in the obese group. This suggests a mechanical role of the abdominal adipose tissue [29].

Current data suggest that fat mass, regardless of its distribution in the body, is positively associated with VTE. Adipose tissue secretes biologically active molecules, hormones, cytokines and growth factors [30]. Between the molecules produced by adipose tissue highlights leptin, this molecule is capable of associating with ADP, inducing platelet aggregation [18]. Moreover, leptin has been shown to correlate with the tPA antigen [17], higher concentrations of inhibitor PAl-1 reduce fibrinolysis, thus favoring the prothrombotic state. Many of the substances secreted by fat tissue are associated with procoagulant activity or inhibition of fibrinolysis. Therefore, it is possible that both the central and peripheral obesity are risk factors for venous thrombosis.

The Framingham Offspring Study evaluated cardiovascular risk factors and their association with prothrombotic factors in 3,230 subjects [31]. Increased BMI and waist-hip ratio were associated with elevated levels of fibrinogen and PAI-1. Furthermore, it has been shown that $\mathrm{BMI}$ and waist-hip ratio levels correlate positively with FVII, FVIIIC, fibrinogen and vWF [31,32].
The results of several studies coincide with ours, and corroborate that overweight is associated with an increased risk of thrombosis, both arterial [33] and venous [34], independently of other risk factors. A Danish population study evaluated the association of different anthropometric parameters (weight, BMI, waist circumference, hip circumference, fat mass) with thrombosis, and found that the risk of VTE increased 2 to 3 times in patients with BMI in the highest quartile compared to the lowest [14]. Many other studies support these findings $[33,35,36]$. One of the most important studies was published by Ageno et al., in 2008. This meta-analysis reviewed the literature from 1386 to 2006, and included 8 studies evaluating the association of obesity $\left(\mathrm{BMI}>30 \mathrm{~kg} / \mathrm{m}^{2}\right)$ and thrombosis. The final OR was 2.33 (95\% Cl: $1.68-2.34)$ [35].

Few studies have evaluated the relationship of obesity with venous thrombosis using parameters other than BMI. Our results are in agreement with those published by Severinsen et al., These authors studied 641 patients with DVT, and estimated a two-fold thrombotic risk in patients with elevated fat mass (kg) (HR: 2.33 for women, and HR 1.89 for men) [15]. In a large case-control study, a positive association between VTE and body weight was found, in addition to BMI [37]. This conclusion resembles that of a study of males that showed a greater risk of VTE for a waist circumference above $100 \mathrm{~cm}$ [38].

\section{Thrombotic complications}

No association with thrombotic recurrence was found for any of the obesity-related parameters included in the study. However, the percentage of patients with $\mathrm{BMI}>25 \mathrm{~kg} / \mathrm{m}^{2}$ (77.6\%) and elevated $\mathrm{BF} \%(61 \%)$ showed a tendency in the relationship between obesity and recurrent thrombosis. The outcome may have been skewed by the low number of patients with recurrence for whom it was possible to determine these parameters could influence. Our results are similar to those obtained by Romuald et al., in 100 patients, of this 58 had abdominal obesity and 42 did not. The main conclusion of the study was that abdominal obesity affects the risk of recurrence [39].

By contrast, a study of 1,107 patients with a mean follow-up of 46 months showed that 168 subjects who had developed 
recurrent events had a significantly higher mean BMI than that of normal-weight patients $\left(28.5 \mathrm{~kg} / \mathrm{m}^{2}\right.$ vs. $26.9 \mathrm{~kg} / \mathrm{m}^{2}$, $\mathrm{p}=0.01$ ); the study found that the risk of recurrence was 1.3 for overweight patients $(95 \% \mathrm{Cl}: 0.9-1,9)$ and 1.6 for obese patients $(95 \% \mathrm{Cl}: 1.1-2,4)[38]$. According to this study by Eichinger et al., the relationship between $\mathrm{BMI}$ and thrombotic recurrence is linear, so small changes in body weight could result in a significant reduction in risk of recurrence. The decreased risk of recurrence could be eliminated if all patients in the study had a normal weight was $26.8 \%$ [40].

When analyzing the relationship with PTS, we also found no differences between patients and controls, and there were no differences between men and women. Although no significant differences were found, $80 \%$ of patients with PTS had a BMI $>25 \mathrm{~kg} / \mathrm{m}^{2}$. The high percentage of patients with elevated BMI in the group of subjects with VTE (73\%) means that the differences are not significant, but reflects once again the importance of obesity and overweight in these patients. The relationship of obesity and overweight in PTS has been studied by different groups. A prospective cohort of 83 consecutive patients with DVT was the subject of a study that assessed weight gain and changes in waist circumference 12 months after the acute event as well as the existence of symptoms compatible with PTS. The BMI of the subjects who developed PTS was higher $\left(29.6 \mathrm{~kg} / \mathrm{m}^{2} \mathrm{vs}\right.$. $27.2 \mathrm{~kg} / \mathrm{m}^{2}, \mathrm{p}=0.02$ ) [41]. Another study conducted in young women showed that BMI $>22 \mathrm{~kg} / \mathrm{m}^{2}$ was associated with the risk of PTS (OR: 4.6) [42]. These results have been subsequently confirmed by other study in a group of 244 patients with DVT, $\mathrm{BMI}>25 \mathrm{~kg} / \mathrm{m}^{2}$ was related to the development of PTS, with an OR of 1.14 [43].

\section{Conclusions}

We found statistically significant positive association between $\mathrm{BMI}, \mathrm{BF} \%$ and $\mathrm{BF}(\mathrm{kg})$ and $\mathrm{VTE}$, we have also observed a trend in the relationship of these parameters with thrombotic complications. However, further studies are needed to explain the mechanism underlying the associations.

\author{
List of abbreviations \\ BF: body fat \\ BMI: body mass index \\ DM: diabetes mellitus \\ DVT: deep venous thrombosis \\ DVT-LL: deep venous thrombosis of the lower limbs \\ DVT-UL: deep venous thrombosis of the upper limbs \\ HDL: high density lipoproteins \\ HDL-C: high density lipoproteins cholesterol \\ HR: hazard ratio \\ UH-FJD: University Hospital Fundación Jiménez Díaz \\ IL-6: Interleukina 6 \\ OR: odds ratio \\ PAI-1: plasminogen activator inhibitor 1 \\ PE: pulmonary embolism \\ PTS: post-thrombotic syndrome \\ TC: total cholesterol \\ TG: triglycerides
}

t-PA: tissue plasminogen activator

VTE: venous thromboembolism

vWF: von Willebrand factor

\section{Competing interests}

The authors declare that they have no competing interests.

Authors' contributions

\begin{tabular}{|l|c|c|}
\hline Authors' contributions & AG & PL \\
\hline Research concept and design & $\checkmark$ & $\checkmark$ \\
\hline Collection and/or assembly of data & $\checkmark$ & -- \\
\hline Data analysis and interpretation & $\checkmark$ & $\checkmark$ \\
\hline Writing the article & $\checkmark$ & -- \\
\hline Critical revision of the article & -- & $\checkmark$ \\
\hline Final approval of article & $\checkmark$ & $\checkmark$ \\
\hline Statistical analysis & $\checkmark$ & $\checkmark$ \\
\hline
\end{tabular}

Publication history

Editor: Randall E. Harris, The Ohio State University, USA.

Received: 13-Mar-2014 Final Revised: 08-Apr-2014

Accepted: 21-Apr-2014 Published: 03-May-2014

\section{References}

1. Cohen AT, Agnelli G, Anderson FA, Arcelus JI, Bergqvist D, Brecht JG, Greer IA, Heit JA, Hutchinson JL, Kakkar AK, Mottier D, Oger E, Samama MM and Spannagl M. Venous thromboembolism (VTE) in Europe. The number of VTE events and associated morbidity and mortality. Thromb Haemost. 2007; 98:756-64. | Article | PubMed

2. Gabriel Botella F. Reflexiones sobre la enfermedad tromboembólica venosa. An. Med. Interna. 2003; 20:5-10. | Pdf

3. S. I.Jiménez, E. Yuste, E. Carrasco and I. Verdú. Manual de referencia SEMERGEN ETV. SEMERGEN \& SCM, Madrid (España) 2006.

4. Joffe HV, Kucher N, Tapson VF and Goldhaber SZ. Upper-extremity deep vein thrombosis: a prospective registry of 592 patients. Circulation. 2004; 110:1605-11. | Article | PubMed

5. M. M. Epidemiología, patogenia e historia natural del tromboembolismo venoso. Manejo práctico del paciente con tromboembolismo venoso. Acción Médica. Madrid. 2002; 1-10

6. Rosendaal FR. Venous thrombosis: a multicausal disease. Lancet. 1999; 353:1167-73. | Article | PubMed

7. FEMI. Enfermedad tromboembólica venosa en España. SEMI y S\&H. Madrid. 2006. I Pdf

8. J. F. Epidemiología y fisiopatología de la trombosis venosa. Hematologica. 2008; 93.

9. Munoz FJ, Mismetti P, Poggio R, Valle R, Barron M, Guil M and Monreal $M$. Clinical outcome of patients with upper-extremity deep vein thrombosis: results from the RIETE Registry. Chest. 2008; 133:143-8. | Article | PubMed

10. Bjorntorp P. Obesity: a chronic disease with alarming prevalence and consequences. J Intern Med. 1998; 244:267-9. | Article | PubMed

11. Danielsson G, Eklof B, Grandinetti A and Kistner RL. The influence of obesity on chronic venous disease. Vasc Endovascular Surg. 2002; 36:271-6. | Article | PubMed

12. Russell $L$ and Allen B. Patient's page. Obesity and you. South Med J. 2008; 101:337. | Article | PubMed

13. Obesidad y riesgo cardiovascular. Rev Esp Nutr. 2003; 9:61-99.

14. Quist-Paulsen P, Naess IA, Cannegieter SC, Romundstad PR, Christiansen $\mathrm{SC}$, Rosendaal FR and Hammerstrom J. Arterial cardiovascular risk factors and venous thrombosis: results from a population-based, prospective study (the HUNT 2). Haematologica. 2010; 95:119-25. 


\section{Article | PubMed Abstract | PubMed Full Text}

15. Severinsen MT, Kristensen SR, Johnsen SP, Dethlefsen C, Tjonneland $A$ and Overvad K. Anthropometry, body fat, and venous thromboembolism: a Danish follow-up study. Circulation. 2009; 120:1850-7. | Article | PubMed

16. Stein PD, Beemath $A$ and Olson RE. Obesity as a risk factor in venous thromboembolism. Am J Med. 2005; 118:978-80. | Article | PubMed

17. Dellas C, Schafer K, Rohm I, Lankeit M, Ellrott T, Faustin V, Riggert J, Hasenfuss $\mathrm{G}$ and Konstantinides $\mathrm{S}$. Absence of leptin resistance in platelets from morbidly obese individuals may contribute to the increased thrombosis risk in obesity. Thromb Haemost. 2008; 100:11239. | Article | PubMed

18. Chu NF, Spiegelman D, Hotamisligil GS, Rifai N, Stampfer M and Rimm EB. Plasma insulin, leptin, and soluble TNF receptors levels in relation to obesity-related atherogenic and thrombogenic cardiovascular disease risk factors among men. Atherosclerosis. 2001; 157:495-503. | Article | PubMed

19. Abdollahi M, Cushman M and Rosendaal FR. Obesity: risk of venous thrombosis and the interaction with coagulation factor levels and oral contraceptive use. Thromb Haemost. 2003; 89:493-8. | Article | PubMed

20. Mohamed-Ali V, Goodrick S, Rawesh A, Katz DR, Miles JM, Yudkin JS, Klein S and Coppack SW. Subcutaneous adipose tissue releases interleukin-6, but not tumor necrosis factor-alpha, in vivo. J Clin Endocrinol Metab. 1997; 82:4196-200. | Article | PubMed

21. Juhan-Vague I, Alessi MC and Vague P. Increased plasma plasminogen activator inhibitor 1 levels. A possible link between insulin resistance and atherothrombosis. Diabetologia. 1991; 34:457-62. | Article | PubMed

22. Pérez S, Parra MD, Martínez de Moretín BE, Rodríguez MC and Martínez JA. Evaluación de la variabilidad intraindividual de la medida de composición corporal mediante bioimpedancia en voluntarias sanas y su relación con el índice de masa corporal y el pliegue tricipital. Enferm Clin. 2005; 15:343-7| Article

23. Kushner RF, Gudivaka R and Schoeller DA. Clinical characteristics influencing bioelectrical impedance analysis measurements. Am J Clin Nutr. 1996; 64:423S-427S. | Article | PubMed

24. Porter JM and Moneta GL. Reporting standards in venous disease: an update. International Consensus Committee on Chronic Venous Disease. J Vasc Surg. 1995; 21:635-45. | Article | PubMed

25. Eklof B, Rutherford RB, Bergan JJ, Carpentier PH, Gloviczki P, Kistner RL, Meissner MH, Moneta GL, Myers K, Padberg FT, Perrin M, Ruckley CV, Smith PC and Wakefield TW. Revision of the CEAP classification for chronic venous disorders: consensus statement. J Vasc Surg. 2004; 40:1248-52. | Article | PubMed

26. Ritchie JD, Miller CK and Smiciklas-Wright H. Tanita foot-to-foot bioelectrical impedance analysis system validated in older adults. J Am Diet Assoc. 2005; 105:1617-9. | Article | PubMed

27. Xie X, Kolthoff N, Barenholt O and Nielsen SP. Validation of a leg-toleg bioimpedance analysis system in assessing body composition in postmenopausal women. Int J Obes Relat Metab Disord. 1999; 23:107984. | Article | PubMed

28. Fronek A, Criqui MH, Denenberg J and Langer RD. Common femoral vein dimensions and hemodynamics including Valsalva response as a function of sex, age, and ethnicity in a population study. J Vasc Surg. 2001; 33:1050-6. | Article | PubMed

29. Willenberg T, Schumacher A, Amann-Vesti B, Jacomella V, Thalhammer C, Diehm N, Baumgartner I and Husmann M. Impact of obesity on venous hemodynamics of the lower limbs. J Vasc Surg. 2010; 52:664-8. | Article I PubMed

30. Darvall KA, Sam RC, Silverman SH, Bradbury AW and Adam DJ. Obesity and thrombosis. Eur J Vasc Endovasc Surg. 2007; 33:223-33. | Article | PubMed

31. Rosito GA, D'Agostino RB, Massaro J, Lipinska I, Mittleman MA, Sutherland P, Wilson PW, Levy D, Muller JE and Tofler GH. Association between obesity and a prothrombotic state: the Framingham Offspring Study. Thromb Haemost. 2004; 91:683-9. I Article | PubMed
32. Allman-Farinelli MA. Obesity and venous thrombosis: a review. Semin Thromb Hemost. 2011; 37:903-7. | Article | PubMed

33. Tsai AW, Cushman M, Rosamond WD, Heckbert SR, Polak JF and Folsom AR. Cardiovascular risk factors and venous thromboembolism incidence: the longitudinal investigation of thromboembolism etiology. Arch Intern Med. 2002; 162:1182-9. | Article | PubMed

34. Garcia-Fuster MJ, Forner MJ, Fernandez C, Gil J, Vaya A and Maldonado L. Long-term prospective study of recurrent venous thromboembolism in patients younger than $\mathbf{5 0}$ years. Pathophysiol Haemost Thromb. 2005; 34:6-12. | Article | PubMed

35. Ageno W, Becattini C, Brighton T, Selby R and Kamphuisen PW. Cardiovascular risk factors and venous thromboembolism: a metaanalysis. Circulation. 2008; 117:93-102. | Article | PubMed

36. Glynn RJ and Rosner B. Comparison of risk factors for the competing risks of coronary heart disease, stroke, and venous thromboembolism Am J Epidemiol. 2005; 162:975-82. | Article | PubMed

37. Pomp ER, le Cessie S, Rosendaal FR and Doggen CJ. Risk of venous thrombosis: obesity and its joint effect with oral contraceptive use and prothrombotic mutations. Br J Haematol. 2007; 139:289-96. | Article | PubMed

38. Hansson PO, Eriksson H, Welin L, Svardsudd K and Wilhelmsen L. Smoking and abdominal obesity: risk factors for venous thromboembolism among middle-aged men: "the study of men born in 1913". Arch Intern Med. 1999; 159:1886-90. | Article | PubMed

39. Romualdi E, Squizzato $A$ and Ageno W. Abdominal obesity and the risk of recurrent deep vein thrombosis. Thromb Res. 2007; 119:687-90. | Article I PubMed

40. Eichinger S, Hron G, Bialonczyk C, Hirschl M, Minar E, Wagner O, Heinze $\mathrm{G}$ and Kyrle PA. Overweight, obesity, and the risk of recurrent venous thromboembolism. Arch Intern Med. 2008; 168:1678-83. | Article | PubMed

41. Ageno W, Piantanida E, Dentali F, Steidl L, Mera V, Squizzato A, Marches $C$ and Venco $A$. Body mass index is associated with the development of the post-thrombotic syndrome. Thromb Haemost. 2003; 89:305-9. I Article | PubMed

42. Biguzzi E, Mozzi E, Alatri A, Taioli E, Moia M and Mannucci PM. The postthrombotic syndrome in young women: retrospective evaluation of prognostic factors. Thromb Haemost. 1998; 80:575-7. | Article | PubMed

43. Van Dongen CJ, Prandoni P, Frulla M, Marchiori A, Prins MH and Hutten $B A$. Relation between quality of anticoagulant treatment and the development of the postthrombotic syndrome. J Thromb Haemost. 2005; 3:939-42. | Article | PubMed

\section{Citation:}

García-Raso A and Llamas Sillero P. Elevated body fat is a risk factor for venous thromboembolism and thrombotic complications. Epidemiol Rep. 2014; 2:3. http://dx.doi.org/10.7243/2054-9911-2-3 